\title{
Early selection in open-pollinated Eucalyptus families based on competition covariates
}

\author{
Bruno Ettore Pavan(1), Rinaldo César de Paula(2), Dilermando Perecin ${ }^{(3)}$, \\ Edimar Aparecido Scarpinati(4) and Liliam Silvia Candido( ${ }^{(5)}$
}

\begin{abstract}
(1)Universidade Estadual Paulista Júlio de Mesquita Filho (Unesp), Faculdade de Engenharia de Ilha Solteira, Rua Monção, no 226, Zona Norte, CEP 15385-000 Ilha Solteira, SP, Brazil. E-mail: pavan@agr.feis.unesp.br (2)Unesp, Faculdade de Ciências Agrárias e Veterinárias (FCAV), Departamento de Produção Vegetal, Campus de Jaboticabal, Via de Acesso Prof. Paulo Donato Castellani, s/no, CEP 14884-900 Jaboticabal, SP, Brazil. E-mail: rcpaula@fcav.unesp.br (3)Unesp, FCAV, Departamento de Ciências Exatas. CEP 14884-900 Jaboticabal, SP, Brazil. E-mail: perecin@fcav.unesp.br ${ }^{(4)}$ Arbogen Tecnologia Florestal, Rua Coronel Quirino, no 1.835, Cambui, CEP 13025-003 Campinas, SP, Brazil. E-mail: eascarpinati@arborgen.com ${ }^{(5)}$ Universidade Federal da Grande Dourados, Faculdade de Ciências Biológicas e Ambientais, Rodovia Itahum-Dourados, Km 12, CEP 79804-970 Dourados, MS, Brazil. E-mail: liliamcandido@ufgd.edu.br
\end{abstract}

Abstract-The objetive of this work was to evaluate the influence of intergenotypic competition in open-pollinated families of Eucalyptus and its effects on early selection efficiency. Two experiments were carried out, in which the timber volume was evaluated at three ages, in a randomized complete block design. Data from the three years of evaluation (experiment 1, at 2, 4, and 7 years; and experiment 2, at 2, 5, and 7 years) were analyzed using mixed models. The following were estimated: variance components, genetic parameters, selection gains, effective number, early selection efficiency, selection gain per unit time, and coincidence of selection with and without the use of competition covariates. Competition effect was nonsignificant for ages under three years, and adjustment using competition covariates was unnecessary. Early selection for families is effective; families that have a late growth spurt are more vulnerable to competition, which markedly impairs ranking at the end of the cycle. Early selection is efficient according to all adopted criteria, and the age of around three years is the most recommended, given the high efficiency and accuracy rate in the indication of trees and families. The addition of competition covariates at the end of the cycle improves early selection efficiency for almost all studied criteria.

Index terms: Eucalyptus, intergenotypic competition, progeny tests, selection methods.

\section{Seleção precoce em famílias de polinização aberta de Eucalyptus com base em covariáveis de competição}

Resumo - O objetivo deste trabalho foi avaliar a influência da competição intergenotípica em famílias de polinização aberta de Eucalyptus e o seu efeito na eficiência da seleção precoce. Foram realizados dois experimentos, nos quais o volume de madeira foi avaliado em três idades, em delineamento de blocos ao acaso. Dados dos três anos de avaliação (experimento 1, aos 2, 4 e 7 anos; e experimento 2, aos 3, 5 e 7 anos) foram analisados a partir de modelos mistos. Foram estimados: componentes de variância, parâmetros genéticos, ganhos com a seleção, número efetivo, eficiência da seleção precoce, ganho com a seleção por unidade de tempo e coincidência de seleção com e sem uso de covariáveis de competição. O efeito da competição não foi significativo em idades inferiores a três anos, e o ajuste por covariáveis de competição foi desnecessário. A seleção precoce para famílias é eficiente; famílias de hábitos de crescimento tardio são mais vulneráveis à competição, o que prejudica de forma mais pronunciada a sua classificação ao final do ciclo. A seleção precoce mostra-se eficiente de acordo com todos os critérios adotados, e a idade em torno de três anos é a mais recomendada, em razão da alta eficiência e do alto índice de acerto na indicação de árvores e famílias. A adição de covariáveis de competição ao final do ciclo melhora a eficiência da seleção precoce para quase todos os critérios estudados.

Termos para indexação: Eucalyptus, competição intergenotípica, testes de progênies, métodos de seleção.

\section{Introduction}

In forestry species, the best age to apply genetic selection is at the end of the commercial cycle, when the tree is ready for logging. At this age, it is possible to make an efficient choice regarding the most productive and best-adapted genotypes for the planting site. However, this species cycle is long, involving high maintenance and evaluation costs, besides low gains per unit time in comparison with other crops.

In this sense, the application of early selection is of great interest, since it maximizes the production 
per selection per unit time and reduces maintenance and evaluation costs for genetic testing. Several methods are used to assess viability and early selection efficiency. Paludzyszyn Filho et al. (2002) evaluated three ways of testing early selection in Pinus taeda and concluded that the sequential method provided the best genetic gain per unit time, but indirect selection was characterized by ease of calculation, with efficiency of $93 \%$ in terms of diameter at breast height. Osorio et al. (2003), Zas et al. (2004), Dean \& Stonecypher (2006), Leksono et al. (2006), Weng et al. (2007), and Beltrame et al. (2012) used the same method to analyze the efficiency of early selection in different tree species.

Many authors reported an interaction between plant genotype and age (Rigão et al., 2009; Massaro et al., 2010), which was predominantly of the simple kind. However, since part of this interaction can be complex, penalizing genotypes that may be of a higher quality, it is very advantageous to detect its cause and minimize or even offset it. It is believed that environmental influence on genetic testing is partially due to intergenotypic competition in adulthood, as shown by some authors (Leonardecz-Neto et al., 2003). However, since this competition can be influential at an early age and the point in which it begins to take effect is unknown, it may also be caused by the genotype vs. age interaction.

Several methods have been used to estimate competition and to differentiate it from genotypic variance, in order to measure the competitive potential of the tree for selection purposes, which would otherwise be ignored (Leonardecz-Neto et al., 2003; Scarpinati et al., 2009); however, the influence of this effect on early selection efficiency is still not known. An increase in competition at ages above the test age may influence variance and heritability (Weng et al., 2007). It is, therefore, important, in studies of early selection, to determine how intergenotypic competition affects selection efficiency, by applying statistical models to correct the bias caused in adulthood and in correlations with juvenile trees. Furthermore, this analysis is important in identifying the age at which competition begins to influence genetic testing, by applying mathematical models to offset competition among young trees.

The objective of this work was to evaluate the influence of intergenotypic competition in open-pollinated Eucalyptus families and its effects on early selection efficiency.

\section{Materials and Methods}

Progeny tests on open-pollinated Eucalyptus, owned by the Brazilian pulp and paper company Fibria (formerly Votorantim Celulose e Papel), were set up in the municipality of Guatapará, SP, Brazil $\left(21^{\circ} 29^{\prime} \mathrm{S}, 4^{\circ} 58^{\prime} \mathrm{W}\right)$. Two experiments were carried out. Experiment 1 (EXP1) was set up in 1996, and experiment 2 (EXP2) in 1999. Growth was evaluated in terms of overall height and circumference at breast height at two, four, and seven years of age in EXP1, and at three, five, and seven years of age in EXP2. These measurements were used to determine merchantable volume with bark, by applying the form factor used by the company. To simulate selection gains, the trees were considered adult at seven years of age (rotation age) in both progeny tests. Trees below this age were considered to be juvenile.

The experimental design was a randomized complete block with six replicates in both experiments. EXP1 consisted of four controls (clones of E. grandis $\mathrm{x}$ E. urophylla, with seven replicates per block, considered as fixed effects) and 49 treatments (open-pollinated families of E. grandis); and EXP2 comprised 44 treatments (families of open-pollinated E. grandis x E. urophylla). The plots were arranged in a linear array, containing ten plants each. A $3.0 \times 2.5 \mathrm{~m}$ spacing was used, with a total progeny test area of 2.39 ha of Eucalyptus for EXP1 and of 1.98 ha for EXP2.

Progenies were assessed based on data on surviving plants in the three evaluated ages. The performance and breeding value of each family and plant for the studied trait were determined by a mixed linear model based on the restricted maximum likelihood (REML) at the three studied ages in EXP1 and for juveniles in EXP2. At age seven in EXP2, the MIVQUE0 procedure was adopted, since REML does not allow convergence to estimate maximum likelihood, making it impossible to estimate the breeding values of individual plants. Two competition covariates for all selection ages were subsequently added to these models, as described below.

The Hegyi competition index (CI) is the aggregated weighted distance of the radius of competition for the forestry trait of trees, considered as competitors of the object tree:

$$
\mathrm{CI}_{\mathrm{i}}=\sum_{\mathrm{j}=1}^{\mathrm{n}}\left(\mathrm{D}_{\mathrm{j}} / \mathrm{D}_{\mathrm{i}}\right) \text { Dist }_{\mathrm{j}},
$$


in which: $\mathrm{CI}_{\mathrm{i}}$ is the tree competition index $\mathrm{i} ; \mathrm{D}_{\mathrm{j}} / \mathrm{D}_{\mathrm{i}}$ is the value of the timber volume trait of competitor $\mathrm{j}$ expressed as a proportion of the volume of object tree $\mathrm{i}$; Dist $\mathrm{ij}_{\mathrm{ij}}$ is the distance between competitor $\mathrm{j}$ and object tree $\mathrm{i}$; and $\mathrm{n}$ is the number of competing trees.

The equation using the nearest eight neighboring trees (competitors) was applied. The arithmetic mean of the forestry trait of the self-competing trees (MSC) was expressed by:

$$
\mathrm{MSC}=\sum_{\mathrm{j}=1}^{\mathrm{n}}\left(\mathrm{j}_{\mathrm{au}} / \mathrm{n}\right),
$$

in which: $\mathrm{j}_{\mathrm{au}}$ is the value of the forestry trait of the self-competitive tree, and $\mathrm{n}$ is the number of self-competitive trees.

These covariates were chosen in accordance with Pavan et al. (2012) and tested for selection of Eucalyptus progenies by Pavan et al. (2011), considerably improving the selection of trees at the end of the cycle. Before analysis of covariance, the linear regression coefficient was tested, since it was significant in both experiments and families $\mathrm{x}$ covariate interaction was nonsignificant, showing that it is possible to use these covariates for analysis. However, for the Hegyi competition index covariate, it was necessary to eliminate trees whose performance was lower than the average by a factor of ten or more.

The best linear unbiased prediction (Blup) method adjusts the data to identifiable environmental effects, such as blocking, and simultaneously predicts genetic value. In this study, genetic values for both families and individuals were obtained simultaneously, ajusted according to blocks and families. Families were evaluated by comparing their classification with and without the use of competition covariates at the three evaluated ages. This was done in order to infer how competition affects their classification and how it acts at different selection ages.

A selection intensity of $4 \%$ for each test and at each age was adopted, simulating selection based on genetic values with and without the use of competition covariates. The performance of trees in each situation and the influence of competition at each age were determined, as well as how the use of covariates affects selection efficiency.

Statistical analysis was performed using the SAS software (SAS Institute, Cary, NC, USA), based on the Proc Mixed REML and MIVQUE0 procedures, with and without the use of covariates. Covariance analysis for the linear mixed model was performed concurrently with prediction simply by adding covariates to the routine analysis.

Each studied trait was assessed at three different ages, with or without covariates, for: genetic parameters, variance components, and descriptive statistics, including overall average (X); heritability $\left(\mathrm{h}_{\mathrm{t}}^{2}\right)$; selected population average (APS); selection gain in absolute terms $\left[\mathrm{SG}=(\mathrm{APS}-\mathrm{X}) \times \mathrm{h}_{\mathrm{t}}^{2}\right]$ and as a percentage in relation to the average $[\mathrm{SG} \%=$ $(\mathrm{SG} / \mathrm{X}) 100]$; genotypic variance between $\left(\hat{\sigma}_{\mathrm{gf}}^{2}\right)$ and within $\left(\hat{\sigma}_{\mathrm{gdf}}^{2}\right)$ families; experimental error between $\left(\hat{\sigma}_{\mathrm{e}}^{2}\right)$ and within $\left(\hat{\sigma}_{\text {ed }}^{2}\right)$ plots; and effective size of the improved population $(\mathrm{Ne})$.

The effective population size was estimated based on the degree of inbreeding, in which: $\mathrm{F}=1 /\left(2 \mathrm{~N}_{\mathrm{e}}\right)$, and, therefore, $\mathrm{N}_{\mathrm{e}}=1 /(2 \mathrm{~F})$, according to Falconer (1987). Based on this principle, Morais (1992) came up with the following expressions, which were used in the present study:

$$
\begin{gathered}
\mathrm{F}_{\mathrm{FMI}_{\mathrm{IZ}}}=\frac{1}{2 \Sigma \mathrm{Ns}}\left[\left(1+\mathrm{F}_{\mathrm{a}}\right)+\left(\mathrm{n}_{\mathrm{iz}}-1\right) \mathrm{r}\right] \\
\mathrm{F}_{\mathrm{FMI}}^{*}=\sum_{\mathrm{Z}}^{1} \mathrm{~F}_{\mathrm{FMI}} / \mathrm{p}_{\mathrm{Z}}^{*} \text {, and } \mathrm{N}_{\mathrm{e}}=1 / 2 \mathrm{~F}_{\mathrm{FMI}}^{*},
\end{gathered}
$$

in which: $\mathrm{F}_{\mathrm{FMI}}$ is the estimated inbreeding coefficient for family $\mathrm{i}$, for trait $\mathrm{z}$, during selection; Ns is the number of selected plants in the experiment; $F_{a}$ is the inbreeding coefficient of selected plants; $\mathrm{n}_{\mathrm{iz}}$ is the number of plants selected for trait $z$ in family $i$; $r$ is the genotypic intraclass correlation coefficient; $\mathrm{F}_{\mathrm{FMI}}^{*}$ is the estimated inbreeding average coefficient for trait $\mathrm{z} ; \mathrm{p}_{\mathrm{Z}}^{*}$ is the number of families selected for trait $\mathrm{z}$; and $\mathrm{N}_{\mathrm{e}}$ is the effective population size.

In applying the above expressions, it was assumed that: the inbreeding coefficient of the selected plants $\left(F_{a}\right)$ is zero, since the $F 1$ population was the one evaluated and it would be necessary to know the genealogy of the progenies in order to obtain the real value of this variable; and the intraclass genotypic correlation coefficient (r) for half-sib families is 0.25 .

Selection coincidence was also evaluated (Coinc 1). It is defined as the percentage of individuals matching the selection under both sets of studied conditions (with and without covariates) at each age, compared to the total selected trees.

Pesq. agropec. bras., Brasília, v.49, n.6, p.483-492, jun. 2014 DOI: 10.1590/S0100-204X2014000600010 
In both experiments and at both juvenile stages, the selection coincidence was also determined for juveniles, with and without the use of covariates, and for adult trees, with and without the use of covariates (Coinc 2), providing four comparisons for each juvenile stage. Coinc 2 was calculated using the same principle as for Coinc 1, changing only the selection situations. For young trees, selection efficiency was also determined by comparing trees selected at an early age and their genotypic values in adulthood, creating a fresh selection gain parameter. This gain parameter was expressed as a percentage of the gain achieved in adulthood $(100 \%)$ and was compared in identical situations to those of Coinc 2. Gain per unit time was calculated for all ages.

Error and the coefficient of variation within plots for EXP1 were estimated based on data from controls (clones, considered as fixed effects), generating a pure error, independent of genotypic variance. In EXP2, genotypic variation within families was estimated by calculating the percentage of each variance component compared to the total variance in EXP1, which was obtained by summing the variance within families and the variance of error; this percentage was used to calculate the error within plots in EXP2. Genotypic variance within families was estimated by subtracting the other variance components $-\hat{\sigma}_{\mathrm{e}}^{2}, \hat{\sigma}_{\mathrm{gf}}^{2}$, and $\hat{\sigma}_{\mathrm{ed}}^{2}-$ from the total variance observed in EXP2. Error within plots for EXP2 is, therefore, similar to the total variance in EXP1. To obtain estimates of variance components and heritability, families were assumed to be half-sib.

\section{Results and Discussion}

Coefficients of variation ranged from 18.89 to $40.05 \%$ in EXP1, and from 19.18 to $44.49 \%$ in EXP2, with significant increases in both experiments between the first two evaluated ages and with a slight decrease at seven years of age (Table 1). Other authors identified coefficients of variation above $25 \%$ for the same trait. Rosado et al. (2012) observed coefficient of variation of $38 \%$ in Eucalyptus clones at 36 months of age, whereas Scarpinati et al. (2009) obtained coefficients of variation that ranged from 26 to $27 \%$. Since volume is derived from two other traits - height and circumference at breast height -, a higher coefficient of variation of $30 \%$ is expected in clonal tests with seven-year-old Eucalyptus. This response can be explained by the continued growth of trees in the field, where they are affected by several uncontrollable environmental variations. The coefficient of variation at two years of age in EXP1 was lower and less influenced by the addition of competition covariates, ranging from 22.83 to $18.89 \%$, showing that competition had little influence on environmental variation. However, at three years of age in EXP2 and in other situations in both experiments, competition covariates had significant influence, significantly reducing the estimates of the coefficients of variation. These results show that intergenotypic competition begins to affect experimental results in juvenile trees. Bouvet et al. (2003), Sebbenn et al. (2005), and Stackpole et al. (2010) found that environmental variation increased with age. This increase is significantly higher during the initial growth phase, tending to stabilize in older trees (Bouvet et al., 2003).

Similar results were obtained for variance components, since the use of covariates had little effect on these parameters at two years of age in EXP1 and, to a lesser degree, at three years of age in EXP2, in comparison to the other assessed ages. These results confirm that competition interferes significantly in genetic testing even in young trees. However, these results cannot be extrapolated to other genetic tests because the level of material competition, as well as the degree of competition generated by plant spacing, soil fertility, and other factors, greatly influences how and when competition will manifest itself. In this respect, Bouvet et al. (2003) reported that competition among families and clones of Eucalyptus increases as they get older, and that this effect was faster and more pronounced at narrower spacings.

In general, the use of covariates caused a drop in expected selection gains (SG) at all ages, except for juveniles in EXP1. However, in EXP1, the level of competition was low at two years of age, and these estimates must, therefore, be incorrect, creating a bias, since the covariates line up to a factor that does not exist, following a false correction. Scarpinati et al. (2009) described the same effect for competition covariates in clonal trials of Eucalyptus at three years of age, in which two of the covariates did not interfere with the analysis and the one that did had an adverse effect on the results. This increase in SG should, therefore, be disregarded.

In EXP1, there was an increase in SG at four years of age with the use of competition covariates, 
mainly due to $\hat{\sigma}_{\text {gdf }}^{2}$, which showed a slight increase, whereas the other parameters decreased, leading to higher heritability, but without harming the average of selected individuals (APS). This fact may be associated with the way competition was manifested at this age in EXP1, when it was able to affect trees in the same portion of clones (control) but not of progenies, which have different growth rates. Bouvet et al. (2003) found that, as time progressed, increased environmental variation was more pronounced in clonal tests than in progeny tests and in narrower plant spacings. This was not the case in EXP2, which showed a higher growth rate than EXP1, indicating that competition plays a more prominent role in younger trees. However, in EXP1, there was a slight decrease in the estimate of $\hat{\sigma}_{\mathrm{gf}}^{2}$, showing that intergenotypic competition affects the magnitude of differences between families at an early age.

Competition had little effect on the rankings of families, causing only a slight change in classification at each age when competition covariates were introduced; however, when the classification of the same families was compared over the years, the families with a late growth spurt were affected by competition in early selection (Table 2). This was the case for families 30 ,
31, and 34 in EXP1, as well as for families 34, 4, and 21, and, to a lesser extent, family 9 in EXP2, which performed well at the end of the cycle, especially when covariates were used. This shows that families that develop later do not present their real potential at the end of the cycle, since they suffer greater suppression from neighbors with different growth habits. These same families are also significantly affected at the beginning of the cycle, because they have not yet shown their real potential for growth.

In EXP1, at four and seven years of age, there was a significant increase in effective number $\left(\mathrm{N}_{\mathrm{e}}\right.$, Table 3$)$ after the introduction of competition covariates, but little variation was observed in $\mathrm{N}_{\mathrm{e}}$ at the age of two years. The introduction of these covariates, however, led to the selection of trees from families that had been selected at two years of age, showing the competition disadvantages of good trees that belong to average families. The competitive effect among families brings benefits to good trees that belong to average families, giving them the opportunity of being selected, but only after correction for the competition effect. This effect was not observed in EXP2, due to low genetic variability among families and to the non-occurrence of families with high selection incidence (Table 4).

Table 1. Variance components and similar parameters without and with the use of competition covariates for the timber volume $\left(\mathrm{m}^{3}\right)$ trait in two experiments (EXP1 and EXP2) testing open-pollinated Eucalyptus families at three ages (years) in Guatapará, state of São Paulo, Brazil.

\begin{tabular}{|c|c|c|c|c|c|c|c|c|c|c|c|c|}
\hline \multirow[t]{3}{*}{ Covariates $^{(1)}$} & \multicolumn{6}{|c|}{ EXP1 } & \multicolumn{6}{|c|}{ EXP2 } \\
\hline & \multicolumn{2}{|c|}{2 years } & \multicolumn{2}{|c|}{4 years } & \multicolumn{2}{|c|}{7 years } & \multicolumn{2}{|c|}{3 years } & \multicolumn{2}{|c|}{5 years } & \multicolumn{2}{|c|}{7 years } \\
\hline & Without & With & Without & With & Without & With & Without & With & Without & With & Without & With \\
\hline$\hat{\sigma}_{\mathrm{gf}}^{2}$ & 0.00004 & 0.00003 & 0.0009 & 0.0006 & 0.0038 & 0.0020 & 0.00007 & 0.00004 & 0.0005 & 0.0002 & 0.00084 & 0.00031 \\
\hline$\hat{\sigma}_{\mathrm{gdf}}^{2}$ & 0.00007 & 0.00006 & 0.0010 & 0.001124 & 0.0043 & 0.0028 & 0.00074 & 0.00048 & 0.0029 & 0.0020 & 0.0081 & 0.0041 \\
\hline$\hat{\sigma}_{\mathrm{e}}^{2}$ & 0.00003 & 0 & 0.0002 & 0.0002 & 0.0012 & 0.0008 & 0 & 0.00003 & 0 & 0.00022 & 0 & 0.00033 \\
\hline$\hat{\sigma}_{\text {ed }}^{2}$ & 0.00004 & 0.00003 & 0.0018 & 0.0011 & 0.0084 & 0.0047 & 0.00097 & 0.00038 & 0.0081 & 0.0029 & 0.0081 & 0.0040 \\
\hline$\hat{\mathrm{h}}_{\mathrm{T}}^{2}$ & 0.63 & 0.76 & 0.49 & 0.58 & 0.46 & 0.47 & 0.45 & 0.56 & 0.30 & 0.41 & 0.53 & 0.51 \\
\hline$\overline{\mathrm{X}}$ & \multicolumn{2}{|c|}{0.027} & \multicolumn{2}{|c|}{0.105} & \multicolumn{2}{|c|}{0.181} & \multicolumn{2}{|c|}{0.101} & \multicolumn{2}{|c|}{0.202} & \multicolumn{2}{|c|}{0.230} \\
\hline APS & 0.050 & 0.049 & 0.191 & 0.190 & 0.354 & 0.328 & 0.185 & 0.161 & 0.426 & 0.357 & 0.529 & 0.450 \\
\hline SG (\%) & $0.014(54)$ & $0.017(62)$ & $0.042(40)$ & $0.050(47)$ & $0.08(44)$ & $0.07(38)$ & 0.038 & $0.034(34)$ & $0.067(33)$ & $0.064(32)$ & $0.16(70)$ & $0.11(48)$ \\
\hline CV (\%) & 22.83 & 18.89 & 40.05 & 31.54 & 36.36 & 27.20 & 30.79 & 19.18 & 44.49 & 26.45 & 39.09 & 27.34 \\
\hline FES & $81.2 / 85.1$ & $80.4 / 83.2$ & $91.3 / 97.5$ & $93.1 / 94.0$ & - & - & $87.7 / 88.7$ & $88.4 / 86.9$ & $97.4 / 98.5$ & $96.2 / 98.8$ & - & - \\
\hline SGUT & $0.03 / 0.03$ & $0.03 / 0.02$ & $0.019 / 0.016$ & $0.018 / 0.016$ & 0.011 & 0.010 & $0.05 / 0.03$ & $0.05 / 0.03$ & $0.03 / 0.02$ & $0.03 / 0.02$ & 0.023 & 0.016 \\
\hline
\end{tabular}

${ }^{(1)} \hat{\sigma}_{g f}^{2}$, genotypic variance between families; $\hat{\sigma}_{g d f}^{2}$, genotypic variance within families; $\hat{\sigma}_{\mathrm{e}}^{2}$, experimental error between plots; $\hat{\sigma}_{\text {ed }}^{2}$, experimental error within plots; $\hat{\mathrm{h}}_{\mathrm{T}}^{2}$, total heritability; X, overall average; APS, average for selected population; SG, selection gain; CV, coefficient of variation; FES, efficiency of early selection in relation to adult selection with and without the use of competition covariates; SGUT, selection gain per unit time (year) in relation to adult selection gain with and without the use of competition covariates. 
This effect seems to be more related to competition among families than among individuals. According to Bouvet et al. (2003), competition seems to have different effects among and within families. The increase in $\mathrm{N}_{\mathrm{e}}$ at four and seven years of age in EXP1 and the recurrence observed in EXP2 is of great interest to plant breeders, since an excessive reduction of the genetic basis, as well as a high level of inbreeding, is a risk to the continuity of breeding programs.

This is further supported by the coincidence of selection (Coinc 1) that was higher in EXP2 than in EXP1 (Tables 3 and 4), showing that intergenotypic competition brings benefits to the best and most competitive families of trees in detriment of the best individuals, since more trees from superior families are selected. This effect was observed in the present study, indicating the 20 best families and their averages in all situations studied in both experiments (Table 2) and the number of individuals selected per family (Tables 3 and 4).

Families with strong initial growth seem to derive some benefits from competition by suppressing neighboring trees early on. Those with a regular growth rate (constant) did not prove to be influenced by competition (for instance, family 29 in EXP1 and family 36 in EXP2). Jansson et al. (2005), when comparing juveniles and adults, reported that genetic parameters are not perfectly estimated for each genetic material. This effect may be the main cause of the genotype $\mathrm{x}$ age interaction cited by other authors.

In general, the classification of the top 20 families has changed little over the years, with or without the introduction of covariates. For younger trees (two and three years of age) evaluated without using covariates, different families were ranked in the top five in adulthood; however, at intermediate ages (four and five years of age), the selected families remained unchanged in EXP1 and only one family changed in EXP2. This means that early selection based on family merit was considered highly efficient, due to the small change in the detection of superior families. However, the adoption of less intensive selection is recommended for trees under four years of age, in order to avoid risking the elimination of families with a late growth spurt.

The efficiency of selection based on the merit of individual trees (Tables 3 and 4 ) is evident when early selection without competition covariates is compared with selection at the end of the cycle, involving the use of competition covariates. In this situation, especially in EXP1, it was observed that trees from average families that were selected at two years of age were also selected at the end of the cycle (Tables 2 and 3 ). The same precautions should be taken when selecting juvenile individuals, since trees which belong to families with a late growth spurt are disadvantaged in early selection. Leksono et al. (2006), working in Indonesia, concluded that the optimum age for selection of E. pellita is around four to five years of age for rotation of eight to nine years.

Introducing competition covariates at two years of age in EXP1 and at three years of age in EXP2 did not improve the efficiency of early selection according to the adopted criteria. However, the correction made at the end of the cycle showed that, in comparison with this situation, early selection is more efficient, because the effects of competition appear in older trees.

The efficiency of early selection at both juvenile ages (Table 1) showed values higher than $80 \%$, compared to the selection of adult trees ready for logging. Dean \& Stonecypher (2006) reported similar results for pinus: at earlier ages, selection efficiency was higher than $80 \%$ and, at intermediate ages, than $95 \%$. Paludzyszyn Filho et al. (2002) observed efficiency of $90 \%$ for diameter at breast height in P. taeda. Although the coincidence of selection (Coinc 2) is lower in EXP1 (around 50 and $70 \%$ at the ages of two and four years, respectively), it does not affect the selection process, since it identifies individuals with above-average expectations, providing good gain estimates.

In EXP1, Coinc 2 was generally higher when early selection was compared to selection at the end of the cycle, without the use of competition covariates (Table 3); however, selection efficiency did not show the same tendency in both tested cases and in juveniles. This suggests that, despite the lower selection coincidence, when competition covariates are used at the end of the cycle, the non-coincident trees selected show superior performance than those in the same situation without the use of competition covariates. This same effect was observed in EXP2, but, considering that the differences in coincidences were generally lower in the tested situations, the selection efficiency for adult trees was higher when competition covariates were used. 
Therefore, the use of competition covariates at the end of the cycle benefited early selection, especially in terms of the increase in $\mathrm{Ne}$, since this parameter was similar for both juvenile and adult trees. However, at very early ages (two and three years), the use of competition covariates did not benefit early selection and is not recommended. At intermediate ages (four and five years), competition covariates had little effect on the efficiency of early selection and matching of selection, although the increase in $\mathrm{Ne}$ and the small changes in family ranking could contribute to a more efficient selection at this age, with the aim of producing

Table 2. Classification of open-pollinated Eucalyptus families mean and genotypic values between parentheses in two experiments (EXP1 and EXP2) at three selection ages for the timber volume $\left(\mathrm{m}^{3}\right)$ trait with and without the use of competition covariates in Guatapará, state of São Paulo, Brazil.

\begin{tabular}{|c|c|c|c|c|c|c|}
\hline \multirow[t]{2}{*}{ Ranking } & \multicolumn{2}{|c|}{$2(\mathrm{EXP} 1)$ or $3(\mathrm{EXP} 2)$ years } & \multicolumn{2}{|c|}{$4(\mathrm{EXP} 1)$ or $5(\mathrm{EXP} 2)$ years } & \multicolumn{2}{|c|}{7 years } \\
\hline & Without & With & Without & With & Without & With \\
\hline & \multicolumn{6}{|c|}{ EXP1 } \\
\hline 1 & $29(0.042)$ & $29(0.040)$ & $04(0.177)$ & $04(0.164)$ & $29(0.319)$ & $30(0.277)$ \\
\hline 2 & $04(0.042)$ & $04(0.039)$ & $29(0.175)$ & $29(0.160)$ & $03(0.310)$ & $29(0.276)$ \\
\hline 3 & 03 (0.039) & $48(0.038)$ & $03(0.167)$ & $03(0.157)$ & $30(0.305)$ & $03(0.270)$ \\
\hline 4 & $46(0.039)$ & $46(0.037)$ & $30(0.162)$ & $46(0.153)$ & $04(0.303)$ & $04(0.267)$ \\
\hline 5 & $02(0.039)$ & $02(0.037)$ & $46(0.157)$ & $30(0.151)$ & $46(0.281)$ & $46(0.255)$ \\
\hline 6 & $30(0.038)$ & $03(0.036)$ & $02(0.150)$ & $02(0.139)$ & $02(0.267)$ & $31(0.246)$ \\
\hline 7 & $47(0.035)$ & $30(0.035)$ & $05(0.147)$ & $05(0.137)$ & $05(0.264)$ & $05(0.239)$ \\
\hline 8 & $06(0.033)$ & $47(0.032)$ & $06(0.142)$ & $06(0.133)$ & $06(0.262)$ & $02(0.233)$ \\
\hline 9 & $05(0.031)$ & $06(0.032)$ & $31(0.133)$ & $31(0.130)$ & $31(0.259)$ & $06(0.231)$ \\
\hline 10 & $12(0.031)$ & $31(0.031)$ & $47(0.129)$ & $08(0.120)$ & $08(0.232)$ & $07(0.223)$ \\
\hline 11 & $31(0.031)$ & $12(0.031)$ & $09(0.125)$ & $47(0.120)$ & $01(0.229)$ & $08(0.222)$ \\
\hline 12 & $08(0.030)$ & $05(0.030)$ & $01(0.122)$ & 09 (0.119) & $07(0.225)$ & $32(0.216)$ \\
\hline 13 & 09 (0.029) & $08(0.029)$ & $08(0.122)$ & $07(0.116)$ & $09(0.225)$ & $09(0.207)$ \\
\hline 14 & $32(0.029)$ & $32(0.029)$ & $32(0.118)$ & $12(0.115)$ & $32(0.220)$ & $12(0.202)$ \\
\hline 15 & $48(0.029)$ & 09 (0.029) & $12(0.117)$ & $32(0.114)$ & $47(0.212)$ & $01(0.195)$ \\
\hline 16 & $01(0.028)$ & $28(0.028)$ & $07(0.115)$ & $01(0.114)$ & $12(0.200)$ & $47(0.186)$ \\
\hline 17 & $36(0.028)$ & $19(0.027)$ & $19(0.115)$ & $48(0.114)$ & $36(0.195)$ & $48(0.186)$ \\
\hline 18 & $19(0.028)$ & $36(0.027)$ & $36(0.114)$ & $23(0.112)$ & $19(0.190)$ & $33(0.184)$ \\
\hline 19 & $28(0.027)$ & $01(0.027)$ & $48(0.112)$ & $19(0.111)$ & $48(0.184)$ & $34(0.184)$ \\
\hline \multirow[t]{2}{*}{20} & $33(0.027)$ & $07(0.027)$ & $10(0.099)$ & $36(0.109)$ & $33(0.163)$ & $19(0.179)$ \\
\hline & \multicolumn{6}{|c|}{ EXP2 } \\
\hline 1 & $42(0.113)$ & $42(0.110)$ & $42(0.242)$ & $37(0.222)$ & $37(0.287)$ & $37(0.263)$ \\
\hline 2 & $36(0.111)$ & $34(0.109)$ & $36(0.241)$ & $36(0.222)$ & $36(0.280)$ & $36(0.259)$ \\
\hline 3 & $37(0.110)$ & $36(0.109)$ & $37(0.237)$ & $42(0.221)$ & $42(0.278)$ & $09(0.256)$ \\
\hline 4 & $43(0.107)$ & $37(0.107)$ & $08(0.227)$ & $08(0.217)$ & $09(0.266)$ & $42(0.254)$ \\
\hline 5 & $09(0.106)$ & $08(0.104)$ & $09(0.225)$ & $09(0.216)$ & $08(0.263)$ & $34(0.253)$ \\
\hline 6 & $35(0.105)$ & $27(0.104)$ & $43(0.225)$ & $34(0.215)$ & $43(0.259)$ & $08(0.247)$ \\
\hline 7 & $08(0.105)$ & $09(0.104)$ & $34(0.222)$ & $11(0.210)$ & $35(0.258)$ & $11(0.246)$ \\
\hline 8 & $27(0.104)$ & $43(0.104)$ & $35(0.219)$ & $43(0.209)$ & $32(0.256)$ & $43(0.242)$ \\
\hline 9 & $34(0.103)$ & $35(0.103)$ & $19(0.214)$ & $14(0.208)$ & $34(0.254)$ & $32(0.240)$ \\
\hline 10 & $23(0.102)$ & $39(0.101)$ & $32(0.213)$ & $32(0.206)$ & $19(0.252)$ & $35(0.240)$ \\
\hline 11 & $39(0.102)$ & $41(0.100)$ & $14(0.213)$ & $27(0.203)$ & $14(0.249)$ & $14(0.239)$ \\
\hline 12 & $41(0.100)$ & $23(0.100)$ & $41(0.211)$ & $20(0.203)$ & $41(0.248)$ & $04(0.238)$ \\
\hline 13 & $32(0.100)$ & $20(0.099)$ & $27(0.208)$ & $35(0.202)$ & $20(0.240)$ & $20(0.238)$ \\
\hline 14 & $20(0.100)$ & $14(0.099)$ & $20(0.204)$ & $04(0.202)$ & $44(0.239)$ & $21(0.238)$ \\
\hline 15 & $15(0.100)$ & $32(0.099)$ & $44(0.204)$ & $19(0.201)$ & $15(0.238)$ & $27(0.236)$ \\
\hline 16 & $14(0.100)$ & $11(0.098)$ & $15(0.203)$ & $44(0.200)$ & $27(0.237)$ & $19(0.236)$ \\
\hline 17 & $28(0.099)$ & $04(0.098)$ & $39(0.200)$ & $39(0.198)$ & $39(0.235)$ & $44(0.235)$ \\
\hline 18 & $30(0.098)$ & $28(0.098)$ & $21(0.199)$ & $21(0.198)$ & $04(0.234)$ & $23(0.232)$ \\
\hline 19 & $19(0.098)$ & $30(0.097)$ & $11(0.198)$ & $23(0.198)$ & $28(0.233)$ & $41(0.232)$ \\
\hline 20 & $10(0.097)$ & $26(0.097)$ & $04(0.197)$ & $41(0.197)$ & $21(0.229)$ & $40(0.231)$ \\
\hline
\end{tabular}


gains in adult trees and continuing the breeding program.

The gain per unit time was significantly higher at an early age when compared to the expected gain at logging age (Table 1). This indicates that selection is more efficient early on rather than at intermediate ages; however, selection at intermediate ages is more efficient than at the end of the cycle. Therefore, due to the high efficiency and good coincidence of the trees and of the families of selected juveniles in relation to the logging age, and to the production of higher earnings per unit time than adult trees, early selection at

Table 3. Number of plants selected in each open-pollinated Eucalyptus family, effective number $\left(\mathrm{N}_{\mathrm{e}}\right)$ and coincidence of trees selected at the same age, with and without the use of covariates (Coinc 1), and selection coincidence for juvenile (two and three years old) and seven-year-old trees, with and without the use of competition covariates (Coinc 2), for the timber volume $\left(\mathrm{m}^{3}\right)$ trait in the first experiment (EXP1).

\begin{tabular}{|c|c|c|c|c|c|c|}
\hline \multirow[t]{2}{*}{ Families } & \multicolumn{2}{|c|}{2 years } & \multicolumn{2}{|c|}{4 years } & \multicolumn{2}{|c|}{7 years } \\
\hline & Without & With & Without & With & Without & With \\
\hline & \multicolumn{6}{|c|}{ Number of selected plants } \\
\hline 1 & 1 & 1 & - & 2 & 1 & 1 \\
\hline 2 & 9 & 8 & 2 & 2 & 2 & 2 \\
\hline 3 & 9 & 9 & 17 & 14 & 19 & 16 \\
\hline 4 & 21 & 19 & 31 & 20 & 19 & 11 \\
\hline 5 & 2 & 1 & 1 & 4 & 5 & 6 \\
\hline 6 & 5 & 5 & 4 & 4 & 5 & 5 \\
\hline 7 & 3 & 3 & 2 & 5 & 5 & 5 \\
\hline 8 & 2 & 2 & 2 & 4 & 3 & 4 \\
\hline 9 & - & - & - & 1 & 1 & 1 \\
\hline 11 & 1 & 1 & - & - & - & - \\
\hline 12 & 4 & 4 & 1 & 4 & 2 & 3 \\
\hline 15 & 2 & 2 & - & - & - & - \\
\hline 18 & - & - & - & 1 & - & - \\
\hline 19 & 2 & 2 & - & 1 & - & 1 \\
\hline 23 & 1 & 2 & - & 2 & - & 2 \\
\hline 24 & 1 & 1 & - & - & - & - \\
\hline 28 & 2 & 3 & - & 1 & - & - \\
\hline 29 & 20 & 18 & 27 & 19 & 23 & 18 \\
\hline 30 & 9 & 9 & 15 & 10 & 19 & 17 \\
\hline 31 & 3 & 3 & 2 & 3 & 4 & 7 \\
\hline 33 & 3 & 3 & - & 1 & - & - \\
\hline 36 & 1 & 1 & - & 1 & - & - \\
\hline 39 & - & - & - & 1 & - & 1 \\
\hline 41 & - & - & - & 1 & - & 2 \\
\hline 46 & 14 & 14 & 13 & 13 & 10 & 10 \\
\hline 47 & 2 & 1 & 1 & 1 & - & 1 \\
\hline 48 & 1 & 5 & - & - & - & 1 \\
\hline$\overline{\mathrm{N}_{\mathrm{e}}}$ & 58.05 & 60.90 & 39.08 & 60.90 & 41.30 & 62.39 \\
\hline Coinc 1 & \multicolumn{2}{|c|}{89.9} & \multicolumn{2}{|c|}{75.4} & \multicolumn{2}{|c|}{83.9} \\
\hline Coinc 2 & $51.7 / 49.1$ & $49.1 / 50.8$ & $77.1 / 63.3$ & $73.7 / 69.5$ & - & - \\
\hline
\end{tabular}

Table 4. Number of plants selected in each open-pollinated Eucalyptus family, effective number $\left(\mathrm{N}_{\mathrm{e}}\right)$ and coincidence of trees selected at the same age, with and without the use of covariates (Coinc 1), and selection coincidence of juvenile (two and four years old) and seven-year-old trees, with and without the use of competition covariates (Coinc 2), for the timber volume $\left(\mathrm{m}^{3}\right)$ trait in the second experiment (EXP2).

\begin{tabular}{|c|c|c|c|c|c|c|}
\hline \multirow{2}{*}{$\overline{\text { Families }}$} & \multicolumn{2}{|c|}{3 years } & \multicolumn{2}{|c|}{5 years } & \multicolumn{2}{|c|}{7 years } \\
\hline & Without & With & Without & With & Without & With \\
\hline
\end{tabular}

\begin{tabular}{|c|c|c|c|c|c|c|}
\hline \multirow[b]{2}{*}{1} & \multicolumn{6}{|c|}{ Number of selected plants } \\
\hline & 2 & 2 & 1 & 1 & 1 & 1 \\
\hline 2 & 3 & 3 & 3 & 3 & 4 & 4 \\
\hline 3 & 1 & 1 & 2 & 1 & 2 & 2 \\
\hline 4 & 5 & 3 & 5 & 4 & 6 & 5 \\
\hline 5 & 4 & 4 & 4 & 4 & 4 & 3 \\
\hline 6 & 2 & 2 & 3 & 3 & 2 & 3 \\
\hline 7 & 1 & 1 & - & - & - & 1 \\
\hline 8 & 2 & 2 & 2 & 2 & 2 & 1 \\
\hline 9 & 2 & 2 & 2 & 2 & 2 & 2 \\
\hline 10 & 1 & 1 & 2 & 2 & 1 & 1 \\
\hline 11 & 3 & 3 & 3 & 3 & 3 & 3 \\
\hline 12 & 2 & 2 & 2 & 2 & 1 & 2 \\
\hline 14 & 3 & 2 & - & - & - & 2 \\
\hline 15 & 4 & 4 & 5 & 6 & 5 & 4 \\
\hline 16 & 2 & 1 & 1 & 1 & 1 & 1 \\
\hline 17 & 4 & 3 & 2 & 2 & 3 & 2 \\
\hline 18 & 1 & - & 2 & 1 & 2 & 1 \\
\hline 19 & 1 & 1 & 3 & 4 & 3 & 3 \\
\hline 20 & 5 & 5 & 6 & 6 & 5 & 5 \\
\hline 21 & 3 & 3 & 4 & 4 & 4 & 4 \\
\hline 22 & 3 & 3 & 4 & 3 & 4 & 4 \\
\hline 23 & 6 & 6 & 6 & 5 & 5 & 4 \\
\hline 24 & 1 & 1 & 1 & 1 & - & - \\
\hline 25 & 2 & 2 & 2 & 2 & 1 & 1 \\
\hline 26 & 2 & 2 & 1 & - & 1 & 1 \\
\hline 27 & 2 & 3 & 2 & 2 & 2 & 2 \\
\hline 28 & 1 & 1 & 2 & 3 & 3 & 3 \\
\hline 29 & 1 & - & 2 & 2 & 1 & 1 \\
\hline 30 & 2 & 3 & 4 & 4 & 5 & 5 \\
\hline 31 & 6 & 7 & 5 & 5 & 5 & 3 \\
\hline 32 & 1 & 2 & - & 1 & 1 & 1 \\
\hline 33 & 1 & 1 & - & - & - & - \\
\hline 34 & 1 & 1 & 1 & 1 & 2 & 1 \\
\hline 35 & 4 & 4 & 3 & 2 & 3 & 4 \\
\hline 36 & 4 & 6 & 3 & 4 & 4 & 5 \\
\hline 37 & 3 & 3 & 2 & 2 & 2 & 2 \\
\hline 38 & 3 & 2 & 4 & 4 & 4 & 4 \\
\hline 39 & 2 & 2 & 1 & 1 & 1 & 1 \\
\hline 40 & 1 & 3 & 1 & 1 & 1 & 2 \\
\hline 41 & - & - & - & - & 1 & 1 \\
\hline 42 & 4 & 4 & 4 & 5 & 3 & 5 \\
\hline 43 & 2 & 3 & 2 & 3 & 2 & 2 \\
\hline 44 & 3 & 2 & 4 & 4 & 4 & 4 \\
\hline$\overline{N_{e}}$ & 76.76 & 75.04 & 73.24 & 73.24 & 74.15 & 75.58 \\
\hline Coinc 1 & \multicolumn{2}{|c|}{88.68} & \multicolumn{2}{|c|}{93.39} & \multicolumn{2}{|c|}{89.62} \\
\hline Coinc 2 & $70.7 / 67.0$ & $68.9 / 66.1$ & $87.7 / 84.9$ & 86.8/81.1 & - & - \\
\hline
\end{tabular}


two or three years of age is recommended for selecting open-pollinated families and individuals of Eucalyptus in a seven-year rotation.

As noted, intergenotypic competition in open-pollinated Eucalyptus progeny tests started from the third year of growth and is more influential from four years onward. Therefore, using competition covariates to offset the competitive effect is not justified for trees under four years of age, considering that, in these juveniles, competition is not a significant factor. The manifestation of competition is directly related to the growth and closure of the forest canopy, when trees begin to compete for light and nutrients. The time at which competition begins is dependent on environmental conditions and plant spacing.

The introduction of competition covariates to offset the competitive effect is an important statistical tool to achieve results that are more consistent with the biological reality of genetic testing. Competition covariates should be incorporated more often in mathematical models used for selection by forest breeders, but inclusion in early selection tests is not required; however, early selection efficiency will be higher than the final selection cycle if competition covariates are used. Further studies are needed in order to assess whether competition covariates and competition itself affect other Eucalyptus progeny tests on different genetic materials and under different edaphoclimatic conditions, in order to define an analysis routine that satisfies the requirements of other situations. Moreover, new studies based on the same criteria are important for other forest species, to ascertain whether there is a standard competitive effect, regardless of the species.

\section{Conclusions}

1. Intergenotypic competition does not influence the efficiency of selection at three years of age in open-pollinated families of Eucalyptus, and adjustment using competition covariates is not recommended at this age.

2. Early selection of families is effective, but families with a late growth spurt are at a disadvantage and may not be selected; these families are also more vulnerable to competition.

3. Early selection is efficient for all the adopted criteria, suggesting that it should be implemented at around three years of age due to its high efficiency and accuracy in indicating superior trees and families.
4. The introduction of competition covariates at the end of the cycle improves early selection efficiency for almost all the studied criteria.

\section{Acknowledgements}

To Conselho Nacional de Desenvolvimento Científico e Tecnológico (CNPq), for fellowships granted.

\section{References}

BELTRAME, R.; BISOGNIN, D.A.; MATTOS, B.F.; CARGNELUTTI FILHO, A.; HASELEIN, C.R.; GATTO, D.A.; SANTOS, G.A. dos. Desempenho silvicultural e seleção precoce de clones de híbridos de eucalipto. Pesquisa Agropecuária Brasileira, v.47, p.791-796, 2012. DOI: 10.1590/ S0100-204X2012000600009.

BOUVET, J.M.; VIGNERON, P.H.; GOUMA, R.; SAYA, A. Trends in variances and heritabilities with age for growth traits in eucalyptus spacing experiments. Silvae Genetica, v.3-4, p.121-133, 2003.

DEAN, C.A.; STONECYPHER, R.W. Early selection of Douglas-fir across south central coastal Oregon, USA. Silvae Genetica, v.55, p.135-141, 2006.

FALCONER, D.S. Introdução à genética quantitativa. Viçosa: Ed. da UFV, 1987. 279p.

JANSSON, G.; JONSSON, A.; ERIKSSON, G. Use of trait combinations for evaluating juvenile-mature relationships in Picea abies (L.). Tree Genetics and Genomes, v.1, p.21-29, 2005. DOI: 10.1007/s11295-005-0003-3.

LEKSONO, B.; KURINOBU, S.; IDE, Y. Optimum age for selection based on a time trend of genetic parameters related to diameter growth in seedling seed orchards of Eucalyptus pellita in Indonesia. Journal of Forest Research, v.11, p.359-364, 2006. DOI: 10.1007/s10310-006-0223-x.

LEONARDECZ-NETO, E.; VENCOVSKY, R.; SEBBENN, A.M. Ajuste para a competição entre plantas em teste progênies e procedências de essências florestais. Scientia Forestalis, n.63, p.136-149, 2003.

MASSARO, R.A.M.; BONINE, C.A.V.; SCARPINATI, E.A.; PAULA, R.C. de. Viabilidade de aplicação da seleção precoce em testes clonais de Eucalyptus spp. Ciência Florestal, v.20, p.597-609, 2010.

MORAIS, O.P. Análise multivariada da divergência genética dos progenitores, índices de seleção e seleção combinada numa população de arroz oriunda de intercruzamento, usando macho-esterilidade. 1992. 251p. Tese (Doutorado)-Universidade Federal de Viçosa, Viçosa.

OSORIO, L.F.; WHITE, T.L.; HUBER, D.A. Age-age and trait-trait correlations for Eucalyptus grandis Hill ex Maiden and their implications for optimal selection age and design of clonal trials. Theoretical and Applied Genetics, v.4, p.735-743, 2003. 
PALUDZYSZYN FILHO, E.; FERNANDES, J.S.C.; RESENDE, M.D.V. de. Avaliação e seleção precoce para crescimento de Pinus taeda. Pesquisa Agropecuária Brasileira, v.37, p.1719-1726, 2002. DOI: $10.1590 / \mathrm{S} 0100-204 X 2002001200007$.

PAVAN, B.E.; PAULA, R.C. de; PERECIN, D.; CANDIDO, L.S.C.; SCARPINATI, E.A. Evaluation of competition effect in Eucalyptus progeny tests. Ciência Florestal, v.22, p.433-443, 2012.

PAVAN, B.E.; PAULA, R.C. de; PERECIN, D.; CANDIDO, L.S.C.; SCARPINATI, E.A. Minimizing inter-genotypic competition effects to predict genetic values and selection in forestry genetic tests. Scientia Agricola, v.68, p.671-678, 2011. DOI: 10.1590/ S0103-90162011000600011.

RIGÃO, M.H.; STORCK, L.; BISOGNIN, D.A.; LOPES, S.J. Correlação canônica entre caracteres de tubérculos para seleção precoce de clones de batata. Ciência Rural, v.39, p.2347-2353, 2009. DOI: $10.1590 / \mathrm{S} 0103-84782009005000190$.

ROSADO, A.M.; ROSADO, T.B.; ALVES, A.A.; LAVIOLA, B.G.; BHERING, L.L. Seleção simultânea de clones de eucalipto de acordo com produtividade, estabilidade e adaptabilidade. Pesquisa Agropecuária Brasileira, v.47, p.964-971, 2012. DOI: 10.1590/ S0100-204X2012000700013.
SCARPINATI, E.A.; PERECIN, D.; PAULA, R.C. de; BONINE, C.A.V.; PAVAN, B.E.; CANDIDO, L.S. Influência do modelo de análise estatística e da forma das parcelas experimentais na seleção de clones de Eucalyptus spp. Revista Árvore, v.33, p.769-776, 2009. DOI: 10.1590/S0100-67622009000400020.

SEBBENN, A.M.; ZANATTO, A.C.S.; FREITAS, M.L.M.; SATO, A.S.; ETTORI, L. de C. Genetic variation in Araucaria cunninghamii provenances in Luiz Antonio-SP, Brazil. Crop Breeding and Applied Biotechnology, v.5, p.435-442, 2005. DOI: 10.12702/1984-7033.v05n04a09.

STACKPOLE, D.J.; VAILLANCOURT, R.E.; AGUIGAR, M. de; POTTS, B.M. Age trends in genetic parameters for growth and wood density in Eucalyptus globulus. Tree Genetics and Genomes, v.6, p.179-193, 2010. DOI: 10.1007/s11295-009-0239-4.

WENG, Y.H.; TOSH, K.J.; PARK, Y.S.; FULLARTON, M.S. Age-related trends in genetic parameters for Jack Pine and their implications for early selection. Silvae Genetica, v.56, p.242-252, 2007.

ZAS, R.; MERLO, E.; FERNÁNDEZ-LÓPEZ, J. Juvenile-mature genetic correlations in Pinus pinaster Ait. under different nutrient $\mathrm{x}$ water regimes. Silvae Genetica, v.3, p.124-129, 2004.

Received on December 20, 2013 and accepted on May 28, 2014 